\title{
Mala colocación de los electrodos: causa de elevación del ST
}

\author{
Dr. Alexis Lama \\ Recibido el 21 de abril 2009. Aceptado 4 de junio 2009
}

Rev Chil Cardiol 2009; 28: 255-256

\section{Sr. Editor:}

Hay muchas causas de elevación del ST. Cuando ésta ocurre en las precordiales derechas, es necesario considerar varios diagnósticos diferenciales, algunos más graves que otros. El síndrome de Brugada puede ser uno de ellos. Gussak, en el año 1999, señaló 17 causas de elevación del segmento ST, específicamente en las precordiales derechas ${ }^{1}$. Sin embargo, es conveniente llamar la atención en una causa no infrecuente de elevación del ST en precordiales derechas, no señalada en la publicación de Gussak. Me refiero a la colocación inadecuada de los electrodos precordiales.

La elevación del ST se ha encontrado en $4.8 \%$ de los pacientes, en los que los electrodos V1 y V2 se colocaron dos espacios intercostales más arriba, es decir en el segundo, manteniendo la referencia de la línea paraesternal correspondiente 2 . Este hecho también ha sido mencionado por Bayés de Luna 2.

Sin embargo, he observado en algunos casos, que la colocación inadecuada del electrodo, específicamente, V2, en el tercer espacio intercostal izquierdo, pero cerca de la línea media clavicular en vez de la línea paraesternal izquierda, produce también una imagen con ST elevado, con una característica agregada en su morfología: tipo silla de montar, que se asemeja al patrón ECG tipo 3 del Brugada (foto 1).
A

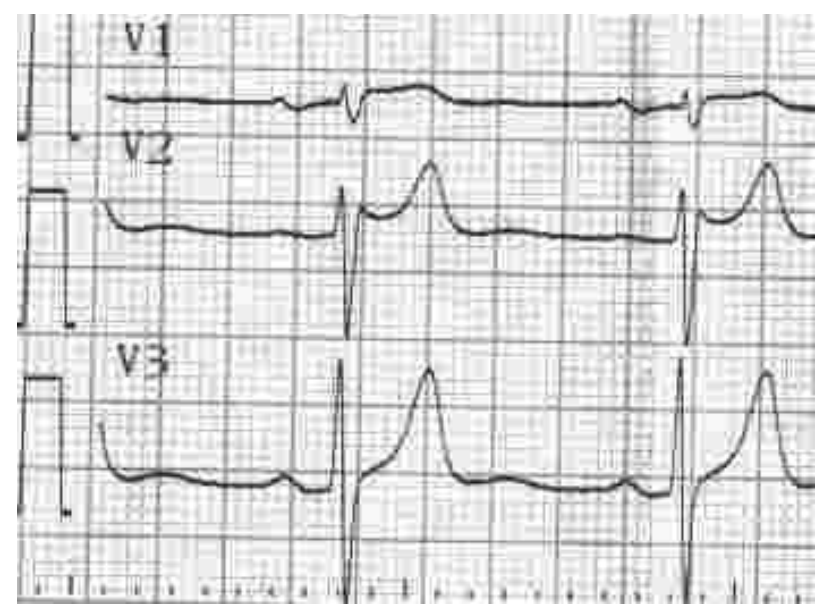

B

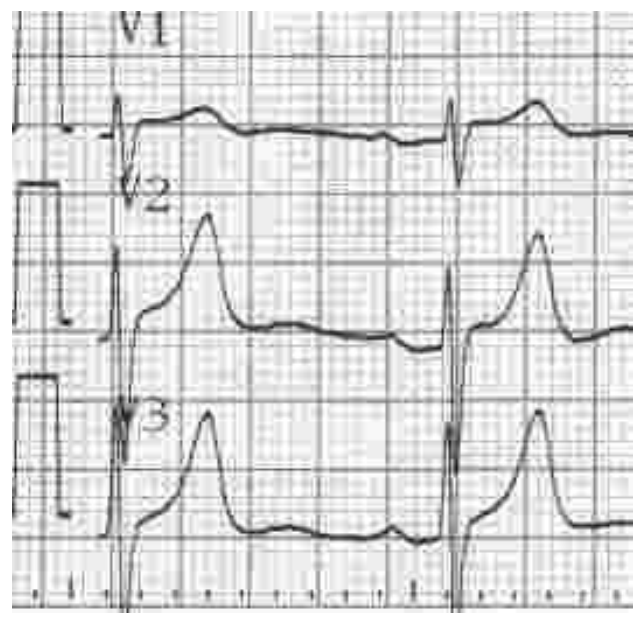

Correspondencia: Dr. Alexis Lama Toro

San Sebastián 2953, Depto. 22 Las Condes

Santiago - Teléfono: 3348454

Correo Electrónico: lamatoro@yahoo.es 


\section{A. Lama}

Por tanto, resulta muy importante, considerar la colocación inadecuada de los electrodos en algunos casos de elevación del ST en precordiales derechas, y velar para que el personal sanitario esté bien capacitado en la técnica de tomar el ECG, y realizar una supervisión de ella periódicamente.

\section{Referencias}

1. GUSSAK I, ANTZELEVITCH C, BJERREGAARD P, TOWBIN JA, CHAITMAN BR. The Brugada syndrome: clinical, electrophysiologic and genetic aspects. J Am Coll Cardiol 1999; 33: 5-15.
2. GARCIA J. Imágenes electrocardiograficas derivadas de una incorrecta colocación de los electrodos V1-V2. Enfermería Canaria 2004; 20; 11-15. 